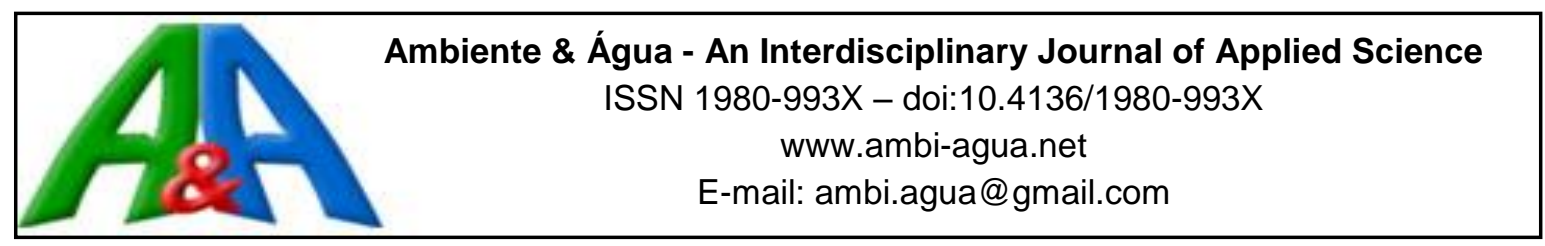

\title{
Assessment of a subtropical riparian forest focusing on botanical, meteorological, ecological characterization and chemical analysis of rainwater
}

\author{
ARTICLES doi:10.4136/ambi-agua.2140
}

Received: 01 Jun. 2017; Accepted: 05 Jan. 2018

\author{
Vanessa Graeff; Ivi Galetto Mottin; Ledyane Rocha-Uriartt; \\ Daniela Montanari Migliavacca Osório*; Jairo Lizandro Schmitt \\ Universidade FEEVALE (FEEVALE), Novo Hamburgo, RS, Brasil \\ Programa de Pós-Graduação em Qualidade Ambiental (PPGQA) \\ E-mail: graeffvanessa@hotmail.com, ivi_mottin@yahoo.com.br, ledyane@gmail.com, \\ danielaosorio@feevale.br, jairols@feevale.br \\ *Corresponding author
}

\begin{abstract}
Riparian forests are heterogeneous environments, in which epiphytes find ideal conditions to develop. These plants absorb the necessary nutrients for survival from the atmosphere, and their occurrence and distribution can be influenced by the quality and quantity of precipitation. The objective of this research was to perform an integrated analysis of botanical, meteorological and chemical precipitation parameters so as to compare them in fragments of the riparian forest in the lower (São Leopoldo-SL) and upper (Caraá-CA) stretches of the Rio dos Sinos Hydrographic Basin (RSHB), RS, Brazil. Rainwater was chemically analyzed, the community structure of epiphytic ferns was surveyed and the ecological characterization was evaluated through the Rapid Habitat Assessment Protocol (RHAP). The results showed that the chemical composition of rainwater is influenced by the environment of each area. In the upper stretch (CA), for instance, the main contribution is that of marine ions, while in the lower stretch (SL), the most impacting aspects are urbanization and industrialization. Similarly, the results depict a reduction of richness and a simplification of the community structure of epiphytic ferns and their environmental quality according to the RHAP categories, towards the base level of the RSHB. The integrated analysis, in which different methods were applied, proved to be an efficient tool to evaluate environmental quality. This analysis considers that a greater number of biotic and abiotic variables may be applied in different scenarios.
\end{abstract}

Keywords: ecological characterization, environmental analysis, epiphytic ferns, rainwater.

\section{Análise integrada de mata ciliar subtropical focando parâmetros botânicos, meteorológicos e químicos da precipitação}

\section{RESUMO}

Matas ciliares são ambientes heterogêneos, no qual, epífitos encontram condições ideais para se desenvolverem. Essas plantas, retiram da atmosfera os nutrientes necessários à sobrevivência, podendo ter sua ocorrência e distribuição influenciada pela qualidade e quantidade das precipitações. $\mathrm{O}$ objetivo foi realizar uma análise integrada de parâmetros 
botânicos, meteorológicos e químicos da precipitação, a fim de compará-los em fragmentos de mata ciliar, nos trechos inferior (São Leopoldo-SL) e superior (Caraá-CA) da Bacia Hidrográfica do Rio dos Sinos (BHRS), RS Brasil. Para tal, foram realizadas análises químicas da água de chuva, analisada a estrutura comunitária das samambaias epifíticas e, avaliada a caracterização ecológica, através do Protocolo de Avaliação Rápida de Hábitats (PARH). Os resultados demonstraram que a composição química da água de chuva é influenciada pelo entorno de cada local estudado, sendo que do terço superior (CA), a maior contribuição é de íons de origem marinha, enquanto que, no trecho inferior (SL), a mesma é oriunda da urbanização e industrialização. Da mesma forma, ficou evidenciada a redução da riqueza e simplificação da estrutura comunitária de samambaias epifíticas e de sua qualidade ambiental de acordo com as categorias do PARH, em direção à foz da BHRS. A análise integrada aplicando diferentes métodos foi uma ferramenta eficiente para avaliar a sua qualidade ambiental, pois permite integrar um maior número de variáveis bióticas e abióticas, podendo ser aplicada em diferentes cenários.

Palavras-chave: água de chuva, análise ambiental, caracterização ecológica, samambaias epifíticas.

\section{INTRODUCTION}

Riparian forests are formations found along waterways (Mueller, 1996), characterized by high-environmental heterogeneity due to the physical and biological interactions in these environments (Rodrigues and Nave, 2000). One of its main functions is to protect the lotic environment and local biodiversity (Gregory et al., 1992). Despite being extremely important and being protected by specific legislation (Brasil, 2012), these environments suffer from fragmentation and edge effects, which end up increasing erosion; consequently, losing a biologically active soil layer, suffering silting and flooding, and to an invaluable loss of biodiversity (Joly et al., 2000).

Rainfall is one of the main processes for the removal of pollutants and chemical compounds from the atmosphere. The natural process of wet deposition results from the combination of chemical compounds and particles, which are removed by droplets or cloud droplets incorporated during precipitation (Seinfeld and Pandis, 2006; Souza et al. 2006; Herrera et al., 2009; Migliavacca et al., 2012). Therefore, rainwater reflects characteristics of the content of soluble gases and the particles of the atmosphere itself (Xiao et al., 2013; Wu et al., 2016).

Epiphytism is a harmonic interaction between two species, in which the epiphyte uses the host plant only as a carrier, removing the nutrients that are necessary for survival (Benzing, 1990). Epiphytes are good indicators of the environmental quality and their monitoring allows researchers to evaluate the effects of forest disturbance, since epiphytic richness has an inverse relation to environmental degradation (Engwald et al., 2000; Barthlott et al., 2001; RochaUriartt et al., 2015). Ferns, which add to $29 \%$ of the species, constitute the second group of vascular plants in terms of epiphytic diversity (Kress, 1986). Thus, they absorb humidity from the air (Benzing, 1990), and may have their occurrence and distribution influenced by the quality and quantity of precipitations.

The Rio dos Sinos Hydrographic Basin (RSHB) is located in the lower northeast of the state of Rio Grande do Sul, southern Brazil. It covers an area of 3,820 $\mathrm{km}^{2}$, in which 32 municipalities are distributed, with a population of approximately $1,343.558$ inhabitants. Of this total, 94\% are residents of urban areas, while only $6 \%$ reside in rural areas (IBGE, 2015). Its main watercourse is Rio dos Sinos, with its source in the municipality of Caraá, which has rural surroundings and it is less impacted. Rio dos Sinos is divided into upper, middle and lower stretches, transcending an urban-industrial matrix at its mouth, near the Jacuí delta 
(PROSINOS, 2014). Kieling-Rubio et al. (2015) and Rocha-Uriartt et al. (2016) surveyed the environmental scenario of this basin, integrating botanical, meteorological and air genotoxicity parameters, based on which they demonstrated the existence of a decreasing gradient of environmental quality from the source to the mouth of Rio dos Sinos.

The objectives of the present study were: I) to evaluate the chemical composition of rainwater in a fragment of riparian forest of the lower stretch of Rio dos Sinos - one of the most important and impacted rivers of Rio Grande do Sul, Brazil; II) to determine the richness, composition and community structure of the epiphytic ferns in the same area; III) to perform ecological characterization in the same environment and IV) to compare the data obtained in I, II and III with the results obtained in the upper stretch of the river.

\section{MATERIALS AND METHODS}

\subsection{Study area}

The present study was carried out in a riparian forest fragment, in the lower stretch of the Rio dos Sinos, Rio Grande do Sul, Brazil. The Imperatriz Leopoldina Park (29 $45^{\prime} 651^{\prime}$ ' S $051^{\circ} 07^{\prime} 928^{\prime \prime}$ O, alt. $26 \mathrm{~m}$ ), where the study area is located, is a Permanent Preservation Area (PPA) of 174 hectares inserted in the municipality of São Leopoldo and is one of the last remnant areas of urban vegetation. The vegetation in the area is altered by antropic action and irregular deposits of residues and, it is frequently inundated during periods of flood of Rio dos Sinos (São Leopoldo, 2016).

The lower stretch of the RSHB is considered a floodplain, with typical vegetation of plains. It presents smooth slopes, typical of lowland rivers, with the formation of meanders and zones of sedimentation. It is also the most anthropogenic stretch of the basin, with a great concentration of population and industries, and with frequent occurrence of erosion processes, deforestation, soil and water pollution (FEPAM, 2016).

The climate of the region is classified as Cfa, humid subtropical (C), with no dry season (f), and with average annual temperature of the hottest month exceeding $22^{\circ} \mathrm{C}$ (a), according to Köppen (Peel et al., 2007).

\subsection{Rainwater}

During the year (Sep/2013 to Aug/2014) rainwater was monitored in the study area and in the region of the source of the Rio dos Sinos. A rainwater collector was installed externally to the rainforest fragment of the Imperatriz Leopoldina Park, and the monthly precipitation data were obtained from meteorological bulletins provided by the automatic meteorological station - Cristo Rei Station (2946’54.72" S; 5109'11.93” O 33 m altitude). For comparison purposes, in the municipality of Caraá, near the source of the Rio dos Sinos, a mobile weather station (Davis Vantage PRO 2 VP USB NS) and another rainwater collector (2944'15.88' ' S; 50²1'34.52', O 375 m altitude) were installed.

Rainwater samples were collected every 15 days, according to the methodology proposed by Migliavacca et al. (2005a). The collectors were always open, both in rainy and dry periods, to sample the atmospheric components of wet (rainfall) and dry deposition (dispersed gases and suspended particles) (Campos et al., 1998). The collectors consisted of a $21.5 \mathrm{~cm}$ diameter polyethylene funnel, $2 \mathrm{~m}$ away from the ground and covered with nylon mesh to prevent the entry of leaves and insects. The funnel was coupled to a $5 \mathrm{~L}$ collection vial and affixed to a metal rod.

After collection, the samples were sent to the laboratory of the Analytical Center of Feevale University for the chemical analyzes. In the unfiltered samples, $\mathrm{pH}$ was checked by using a digital pHmeter (Digimed DM-20, precision \pm 0.01 ) and conductivity was surveyed by using a conductivity meter (Quimis Q795M2, precision \pm 0.01 ), both previously calibrated. For 
alkalinity, the analysis was performed according to APHA (2012). Subsequently, two aliquots, approximately $100 \mathrm{~mL}$, were filtered through a cellulose ester membrane $(0.22 \mu \mathrm{m}$ pore and $47 \mathrm{~mm}$ diameter). In order to determinate major ions, the samples were preserved with chloroform and for the determination of metals, preserved with Supra Pure $\mathrm{HNO}_{3}$ (MERCK) up to $\mathrm{pH}<2$. Subsequently, these samples were stored at $4^{\circ} \mathrm{C}$, up to a maximum of 30 days, for chemical analysis.

The major ions were determined by ion chromatography (Dionex ICS 5000 with electrical conductivity detector). The Dionex IonPac TM AS9-HC and CS12A columns were used for analyzing the anions $\left(\mathrm{Cl}^{-}, \mathrm{NO}_{3}{ }^{-}\right.$and $\left.\mathrm{SO}_{4}{ }^{2-}\right)$ and cations $\left(\mathrm{Na}^{+}, \mathrm{Ca}^{2+}, \mathrm{Mg}^{2+}, \mathrm{K}^{+}\right.$and $\left.\mathrm{NH}_{4}^{+}\right)$, respectively. The limits of detection were: $0.01 \mathrm{mg} \mathrm{L}^{-1}$ for $\mathrm{Cl}^{-} ; 0.05 \mathrm{mg} \mathrm{L}^{-1}$ for $\mathrm{NO}_{3}^{-}, \mathrm{SO}_{4}{ }^{2-}$, $\mathrm{Na}^{+}, \mathrm{NH}_{4}^{+}, \mathrm{K}^{+}$and $\mathrm{Ca}^{2+}$ and $\mathrm{Mg}^{2+}$.

The analysis of metals ( $\mathrm{Al}, \mathrm{Pb}, \mathrm{Cd}, \mathrm{Cu}, \mathrm{Cr}, \mathrm{Fe}, \mathrm{Mn}$ ) was performed by using the Atomic Flame Absorption Spectrometry method (SpectrAA 110, VARIAN). All of the calibration solutions were prepared by dilutions in ultrapure water of Titrisol (Merck) standards of each metal. Detection limits were $0.0005 \mu \mathrm{g} \mathrm{L}^{-1}$ for $\mathrm{Al} ; 0.12 \mu \mathrm{g} \mathrm{L}^{-1}$ for $\mathrm{Cd} ; 0.80 \mu \mathrm{g} \mathrm{L}^{-1}$ for $\mathrm{Pb} ; 0.10 \mu \mathrm{g} \mathrm{L}{ }^{-1}$ for $\mathrm{Cu} ; 0.11 \mu \mathrm{g} \mathrm{L}^{-1}$ for $\mathrm{Cr} ; 5.7 \mu \mathrm{g} \mathrm{L}{ }^{-1}$ for $\mathrm{Fe} ; 0.15 \mu \mathrm{g} \mathrm{L}^{-1}$ for $\mathrm{Ni}$ and $5.8 \mu \mathrm{g} \mathrm{L}^{-1}$ to $\mathrm{Zn}$.

The data of the accumulated precipitation and chemical composition of rainwater were submitted to the Shapiro-Wilk normality test. The $\mathrm{pH}, \mathrm{Na}^{+}$and $\mathrm{Ca}^{2+}$ and accumulated precipitation met the normality assumption. The t-test was used for comparison purposes. Further data did not meet normality, being compared by the Mann-Whitney test. These analyzes were conducted using PAST software.

The Enrichment Factor (EF) can be used to estimate the main sources of chemical components present in rainwater (Song and Gao, 2009). In the present study, two EF were used to estimate anthropic, marine and terrestrial crust sources. The Enrichment Factor for marine origin (EFm) (Equation 1) was used as the reference ion $\mathrm{Na}^{+}$and the marine ratio $\left(\mathrm{Xi} / \mathrm{Na}^{+}\right)$ according to Akkoyunlu and Tayan (2003). For the Earth's Crust Enrichment Factor (EFc) (Equation 2) $\mathrm{Al}$ and the ratio (Xi/Al) were used as the reference ion, according to Taylor and McLennan (1995). The EF were calculated according to the equations below, where $\mathrm{X}$ is the concentration of the reference ion and $\mathrm{Xi}$ is the concentration of the ions of interest:

EFm $=\frac{\left(\mathrm{X} / \mathrm{Na}^{+}\right) \text {sample }}{\left(\mathrm{X} / \mathrm{Na}^{+}\right) \text {marine }}$

$E F C=\frac{(X / A l) \text { sample }}{(X / A l) \text { marine }}$

EF was interpreted using a scale according to Poissant et al. (1994) in which EF from 1 to 10 indicate marine or terrestrial crust contribution, consequently a low EF; EF> 10 to 500 moderate enrichment and over 500, extreme enrichments.

\subsection{Floristic inventory and community structure}

Throughout the riparian vegetation, a continuous transect of 800 meters, parallel to the course of the river was traced. An arboreal individual was selected at every $20 \mathrm{~m}$, totaling 40 sample units in the fragment. These were divided into five ecological zones based on height (1 base, 2 low shaft, 3 high shaft, 4 inner cup, and 5 external cup).

For the inventory of the epiphytic ferns, monthly visits were carried out for one year. Representative and fertile specimens were collected and herborized according to Windisch (1992). The classification of epiphytic ferns followed the system proposed by Schuettpelz et al. (2016) and the validity of scientific names was verified in the List of Species of the Brazilian 
Flora (Prado and Sylvestre, 2016). Sample specimens were deposited in the Herbarium Anchieta (PACA), from the Anchietano Institute of Research (UNISINOS).

For the community structure, coverage notes $(1,3,5,7$ and 10) were given for each species according to size and abundance in the area of occurrence (Kersten and Waechter 2011). The epiphytic importance value (IVs) was obtained from the arithmetic mean of the sum of the relative frequencies in the phorophytes, in the zones and the relative coverage.

The floristic composition and the community structure of the present study were compared to the inventory performed by Becker et al. (2014), in a riparian forest, in the source of the Rio dos Sinos, in the municipality of Caraá, upper stretch of the basin.

\subsection{Rapid Habitat Assessment Protocol}

The rapid habitat assessment protocol (RHAP) was applied in the study area. The protocol was adapted from the Environmental Protection Agency (USEPA, 1987), Barbour et al. (1999) and Callisto et al. (2002). Sixteen parameters were analyzed based on visual observations: 1. Type of occupation of the margins; 2. Erosion on the banks and silting of the river; 3. Anthropogenic alterations; 4. Vegetation cover on the river channel; 5. Water odor and sediment; 6. Water and sediment oils; 7. Water transparency; 8. Type of background (composition); 9. Type of bed (diversification); 10. Extension and frequency of rapids; 11 . Type of substrate; 12. Sedimentary deposits; 13. Changes in the river channel; 14. Water flow characteristics; 15 . Stability of the margins; 16. Extension of riparian forest. After applying the protocol, the sum of points of each parameter was performed, which were converted into the scale proposed by Callisto et al. (2002) in which the obtained values represent: from 0 to 40 points - impacted stretch; from 41 to 60 points - altered stretch; from 61 to 100 points - natural stretch.

The rapid habitat assessment protocol (RHAP) of the present study was compared to the study by Rocha-Uriartt et al. (2015), which was undertaken also along the riparian forest of Rio dos Sinos.

\section{RESULTS AND DISCUSSION}

\subsection{Rainwater}

The accumulated precipitation was $1842.2 \mathrm{~mm}$ e $2548.2 \mathrm{~mm}$ in São Leopoldo and in Caraá, respectively, and there was no significant difference during the evaluated period $(t=1.81, \mathrm{p}>0.05)$ (Table 1). However, Rocha-Uriartt et al. (2015) showed that, when the precipitation is monitored over a longer period, precipitation tends to be significantly higher in the Rio dos Sinos source region than in the lower stretch of the basin.

The cumulative monthly precipitation was equivalent in the month of Sep/2014 in the two areas (124.6 $\mathrm{mm}$ and $122.7 \mathrm{~mm}$, respectively). The minimum precipitation in São Leopoldo occurred in March 2014 (95.5 mm) and Caraá in October 2013 (94.0 mm). During February 2014, the highest precipitation was recorded in São Leopoldo $(253.3 \mathrm{~mm})$, and in Caraá this occurred in June 2014 (420.4 mm) (Figure 1). Rocha-Uriartt et al. (2015) recorded, in Caraá, twice the maximum value of accumulated monthly precipitation in relation to the lower stretch (Caraá: $698.8 \mathrm{~mm}$ and Campo Bom: $370.3 \mathrm{~mm}$ ). 
Table 1. Average \pm standard deviation of physical-chemical parameters and precipitation enrichment factor in Caraá and São Leopoldo.

\begin{tabular}{|c|c|c|c|c|c|c|c|c|c|c|c|}
\hline \multirow[t]{2}{*}{ Parameter } & \multirow[t]{2}{*}{ Unit } & \multicolumn{3}{|c|}{ Caraá } & \multicolumn{5}{|c|}{ São Leopoldo } & & \multirow[t]{2}{*}{$\mathrm{p}$ value } \\
\hline & & Min & Average \pm SD & Max & $\mathrm{EF}$ & Min & Average \pm SD & Max & $\mathrm{EF}$ & & \\
\hline & & & & & & & & & & t-test & \\
\hline Precipitation & $(\mathrm{mm})$ & 94.00 & $2548.2 \pm 97.36$ & 420.40 & -- & 95.50 & $1842.2 \pm 56.20$ & 253.5 & -- & 1.81 & 0.08 \\
\hline $\mathrm{pH}$ & & 5.25 & $6.14 \pm 0.48$ & 6.77 & -- & 5.29 & $6.24 \pm 0.51$ & 7.13 & -- & -0.50 & 0.62 \\
\hline $\mathrm{Na}^{+}$ & $\left(\mu\right.$ eq $\left.\mathrm{L}^{-1}\right)$ & 2.83 & $43.76 \pm 21.14$ & 74.62 & -- & 5.49 & $22.60 \pm 18.46$ & 72.28 & -- & 2.45 & 0.02 \\
\hline \multirow[t]{2}{*}{$\mathrm{Ca}^{2+}$} & $\left(\mu \mathrm{g} \mathrm{L}^{-1}\right)$ & 2.99 & $49.78 \pm 26.77$ & 100.55 & $32 *$ & 2.49 & $38.57 \pm 36.50$ & 117.68 & $47 *$ & 0.84 & 0.40 \\
\hline & & & & & & & & & \multicolumn{3}{|c|}{ Mann-Whitney } \\
\hline Conductivity & $\left(\mu \mathrm{S} \mathrm{cm}^{-1}\right)$ & 6.41 & $19.23 \pm 17.15$ & 71.35 & -- & 6.16 & $12.71 \pm 7.52$ & 33.15 & -- & 42.0 & 0.14 \\
\hline $\mathrm{N}-\mathrm{NH}_{4}{ }^{+}$ & $\left(\mu\right.$ eq $\left.L^{-1}\right)$ & 4.44 & $30.44 \pm 25.63$ & 75.50 & -- & 2.81 & $53.51 \pm 66.90$ & 166.96 & -- & 23.0 & 0.85 \\
\hline $\mathrm{N}-\mathrm{NO}_{3}^{-}$ & $\left(\mu\right.$ eq $\left.L^{-1}\right)$ & 0.69 & $11.80 \pm 7.18$ & 28.33 & -- & 0.80 & $7.10 \pm 11.50$ & 33.51 & -- & 34.0 & 0.06 \\
\hline $\mathrm{Cl}^{-}$ & $\left(\mu\right.$ eq $\left.L^{-1}\right)$ & 6.68 & $74.50 \pm 49.34$ & 177.09 & $2 *$ & 9.99 & $32.70 \pm 28.15$ & 91.93 & $2^{*}$ & 21.0 & 0.06 \\
\hline $\mathrm{SO}_{4}^{2-}$ & $\left(\mu\right.$ eq $\left.\mathrm{L}^{-1}\right)$ & 6.26 & $45.84 \pm 29.91$ & 91.25 & $10 *$ & 3.63 & $20.58 \pm 27.20$ & 97.35 & $7 *$ & 24.0 & 0.03 \\
\hline $\mathrm{K}^{+}$ & $\left(\mu\right.$ eq $\left.\mathrm{L}^{-1}\right)$ & 2.14 & $38.16 \pm 34.54$ & 135.66 & $56^{*}$ & 1.26 & $11.01 \pm 11.04$ & 36.55 & $24 *$ & 21.0 & $<0.01$ \\
\hline $\mathrm{Mg}^{2+}$ & $\left(\mu\right.$ eq $\left.\mathrm{L}^{-1}\right)$ & 44.90 & $60.18 \pm 16.12$ & 87.22 & $5^{*}$ & 2.05 & $9.03 \pm 5.70$ & 20.8 & $2 *$ & 0.0 & $<0.01$ \\
\hline $\mathrm{Pb}$ & $\left(\mu \mathrm{g} \mathrm{L}^{-1}\right)$ & 0.24 & $0.64 \pm 0.49$ & 2.12 & $1 * *$ & 0.27 & $0.75 \pm 0.70$ & 1.76 & $1 * *$ & 21.0 & 0.71 \\
\hline $\mathrm{Al}$ & $\left(\mu \mathrm{g} \mathrm{L}^{-1}\right)$ & 2.04 & $12.30 \pm 11.40$ & 30.00 & $15^{* *}$ & 1.12 & $12.76 \pm 17.30$ & 50.61 & $13 * *$ & 50.0 & 0.75 \\
\hline $\mathrm{Cd}$ & $\left(\mu \mathrm{g} \mathrm{L}^{-1}\right)$ & 0.002 & $0.04 \pm 0.05$ & 0.11 & $3229 * *$ & 0.11 & $0.28 \pm 0.24$ & 0.45 & $14838 * *$ & 2.0 & 0.09 \\
\hline $\mathrm{Cu}$ & $\left(\mu \mathrm{g} \mathrm{L}^{-1}\right)$ & 0.05 & $1.13 \pm 1.31$ & 4.19 & $552 * *$ & 0.10 & $1.64 \pm 2.60$ & 8.63 & $4899 * *$ & 56.0 & 0.79 \\
\hline Cr Total & $\left(\mu \mathrm{g} \mathrm{L}^{-1}\right)$ & 0.02 & $0.04 \pm 0.01$ & 0.06 & $17 * *$ & 0.02 & $0.50 \pm 0.50$ & 1.09 & $82 * *$ & 1.50 & $<0.01$ \\
\hline $\mathrm{Fe}$ & $\left(\mu \mathrm{g} \mathrm{L}^{-1}\right)$ & 0.02 & $12.95 \pm 10.60$ & 31.10 & $4 * *$ & 3.63 & $24.54 \pm 31.54$ & 106.1 & $13 * *$ & 57.0 & 0.60 \\
\hline $\mathrm{Mn}$ & $\left(\mu \mathrm{g} \mathrm{L}^{-1}\right)$ & 0.06 & $6.16 \pm 8.70$ & 32.19 & $142 * *$ & 0.007 & $2.16 \pm 2.55$ & 7.67 & $144 * *$ & 38.0 & 0.09 \\
\hline
\end{tabular}

Legend: EF: Enrichment Factor;* marine EF; ** crust EF; p value: significance level of 5\%. 


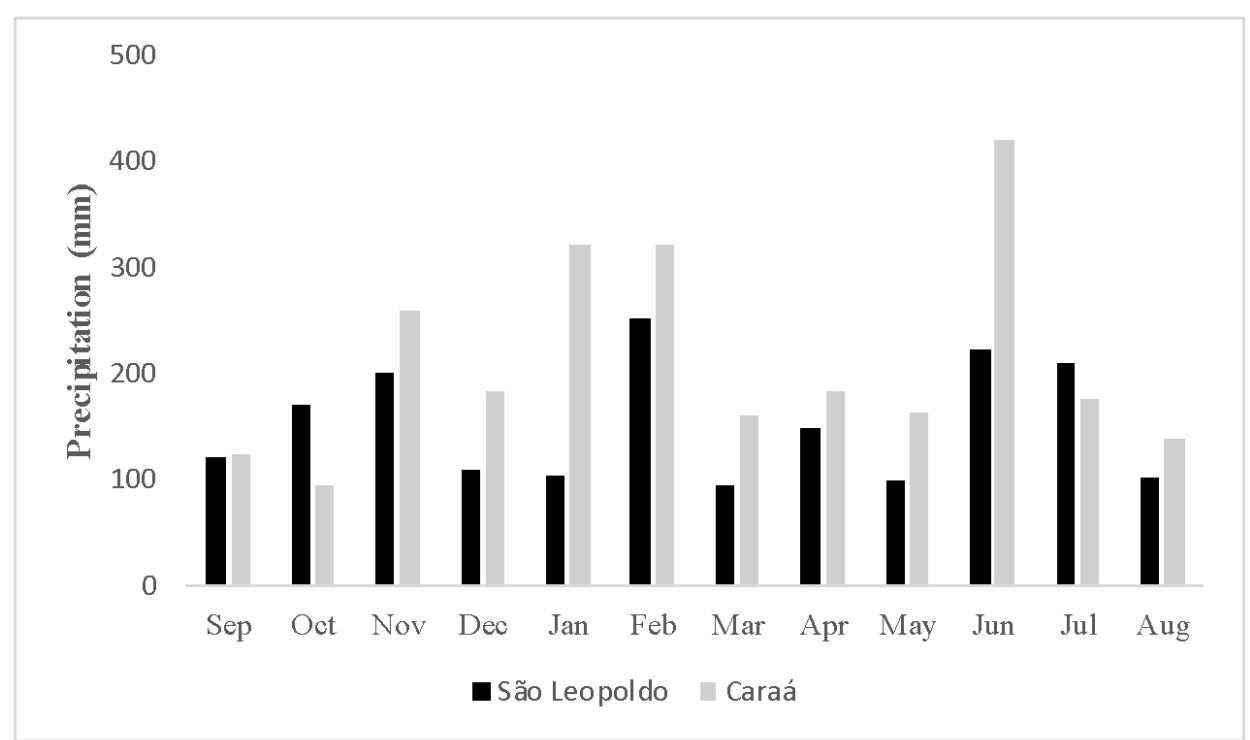

Figure 1. Monthly accumulated precipitation in a 12-month period at São Leopoldo and Caraá.

In the analysis of rainwater, the ions $\mathrm{SO}_{4}{ }^{2-}, \mathrm{Na}^{+}, \mathrm{K}^{+}$and $\mathrm{Mg}^{2+}$ showed significantly higher average concentrations in Caraá than the concentrations recorded in São Leopoldo. Only Cr T had a significantly higher concentration in São Leopoldo than in Caraá (Table 1). The values of conductivity, $\mathrm{pH}$ and other ions and metals did not present significant differences between the study sites.

Only in $18 \%$ of the events (4) the $\mathrm{pH}$ was lower than 5.6, which characterizes acid rain. Thus, for the studied sites, a slightly alkaline $\mathrm{pH}$ can be considered when compared to the rainfall reference value (Seinfeld and Pandis, 2006). The presence of alkaline compounds in rainwater, such as $\mathrm{NH}_{3}$ and carbonates, aid in its neutralization process. Alkaline $\mathrm{pH}$ values were also recorded in the Guaíba Hydrographic Basin (Migliavacca et al., 2005b) in 16\% of samples, and in the Metropolitan Region of Porto Alegre in 22\% of samples (Migliavacca et al., 2012), both located near the Rio dos Sinos basin.

The marine enrichment factor (EFm) for the analyzed elements followed the sequence $\mathrm{K}^{+}>\mathrm{Ca}^{2+}>\mathrm{SO}_{4}{ }^{2-}>\mathrm{Mg}^{2+}>\mathrm{Cl}^{-}$in Caará and $\mathrm{Ca}^{2+}>\mathrm{K}^{+}>\mathrm{SO}_{4}{ }^{2-}>\mathrm{Mg}^{2+}>\mathrm{Cl}^{-}$in São Leopoldo (Table1). The presence of sulfate $\left(\mathrm{SO}_{4}{ }^{2-}\right)$ in the atmosphere comes from natural sources such as the oxidation of dimethyl sulphide $\left(\mathrm{CH}_{3} \mathrm{SCH}_{3}\right)$ emitted by ocean waters (Oliveira Junior et al., 2015). The EFm for this chemical compounds was low, reinforcing the indication of the presence of marine ions in rainwater samples (Oliveira Junior et al., 2015), especially in Caraá, where it was significantly larger. This occurs, therefore, in the source of Rio dos Sinos, which is located approximately $32 \mathrm{~km}$ in a straight line from the Atlantic Ocean, confirming the influence of rainwater in these ions. In addition, $\mathrm{Na}^{+} \mathrm{e} \mathrm{Cl}^{-}(\mathrm{EFm}=4$ low $)$, which are ions derived from marine aerosols (Migliavacca et al., 2005a; 2005b) were also detected in high concentrations in Caraá. In fact, $\mathrm{Na}^{+}$was significantly higher at the site.

Incorporation of $\mathrm{Mg}^{2+} \mathrm{e} \mathrm{K}^{+}$(low and moderate EFm, respectively) comes from soil dust, by the dissolution of minerals, silicates or by arable soils that have traces of fertilizers. These can then release particulate material into the atmosphere during precipitation (Sardinha et al., 2013). These ions were significantly higher in Caraá, which is an essentially a rural municipality, and could have been incorporated to the rain of the region (Table 1).

The enrichment factor for $\mathrm{Ca}^{2+}$ enrichment may be related to the dissolution of $\mathrm{CaCO}_{3}$ present in suspended soil dust, due to the intense vehicular traffic (Migliavacca et al., 2012), mainly in São Leopoldo, where a moderate EFm (47) was verified. This result reinforces the possible anthropic origin for this ion in rainwater samples. The Imperatriz Leopoldina Park is 
directly influenced by vehicular sources coming from the highway BR-116, Imperatriz Leopoldina and Mauá avenues, and from the downtown area of the municipality, corroborating with the high concentration of these metals in the rainwater (Blume et al., 2014; Costa et al., 2016).

The concentrations of $\mathrm{NO}_{3}^{-}$and $\mathrm{NO}_{2}^{-}$are derived from agricultural sources, from phosphate fertilizers, in which the $\mathrm{NH}_{4}{ }^{+}$ion can be converted to $\mathrm{NH}_{3}$ by chemical reactions in the atmosphere and potentiate the process of rainwater neutralization (Migliavacca et al., 2012). The presence of these ions comes from subsistence agriculture and monocultures of rice in the upper and lower stretches of the RSHB, respectively. (Roy et al., 2016).

The crust Enrichment Factor $(\mathrm{EFc})$ values (Table 1) ranged from 1 to 9034, with an EFc of less than 10 for $\mathrm{Pb}$ and $\mathrm{Fe}$ (only in Caraá), indicating a low enrichment of rainwater samples from the terrestrial crust. The presence of $\mathrm{Pb}$ in rainwater does not come from the Earth's crust and its origin may be related to the enrichment of particles originating from anthropic sources, such as coal combustion, founding and vehicular emissions (Migliavacca, et al., 2012, Wu et al., 2016, Herrera et al., 2009). As to the other metals, $\mathrm{Cr}>\mathrm{Cu}>\mathrm{Cd}$, a strong (Cr) to extreme $(\mathrm{Cu}$ and $\mathrm{Cd})$ enrichment is observed.

The $\mathrm{Cu}$ and $\mathrm{Cd}$ elements are derived from vehicular emissions because they are present in practically all types of brake linings and are used for tire manufacturing (Manahan, 2005; Alleman et al., 2010; Moreira, 2010; Loyola et al., 2012; Alves et al., 2015). The extreme EFc values for both study areas, especially in the lower stretch of the RSHB, show that the contribution of vehicular traffic dust is incorporated into precipitation, especially in São Leopoldo. This is confirmed by the higher vehicular fleet in this municipality (74.412 vehicles) than in Caraá (1.531 vehicles) (IBGE, 2017). Costa et al. (2016), who counted vehicles in an area near Imperatriz Leopoldina Park in São Leopoldo, indicated that the circulation of vehicles over an hour is from 1420 to 2349. In São Leopoldo, the significantly higher concentration of total chromium $(\mathrm{Cr} \mathrm{T})$ is related to the great industrialization of the lower stretch of the RSHB, derived from steel and metallurgical processes, and especially from leather tanning (Alves et al., 2015) in the studied region.

\subsection{Floristic Inventory and community structure}

Seven species were inventoried. They belong to five genera and two families, being Polypodiaceae with six species and Dryopteridaceae with only one species (Table 2). The analysis of distribution of epiphytic ferns along the RSHB shows a simplification in the richness and a change in the floristic composition of the area. Studies that applied the same methodology demonstrate the same results. For instance, Becker et al. (2014) recorded 30 species near the source of the Rio dos Sinos in Caraá, out of which only three were shared with the present study. Barbosa et al. (2015), in a study carried out in an urban park in the lower stretch of the basin, recorded only nine species of epiphytic ferns, four of which were shared with this study. This fact may be associated to vegetation and environment characteristics, since epiphytes, especially ferns, need a healthy environment to develop (Johansson, 1974) and Rocha-Uriartt et al. (2015) showed that there is a decreasing gradient in vegetation degradation from the source towards the mouth of the river in the RSHB.

The community structure of the present study did not present an equitable distribution, since the three most important species of the community (Microgramma vaccinifolia, Pleopeltis pleopeltifolia and M. squamulosa) contribute with more than $95 \%$ of IVs. The other species (four) registered less than 5\% of IVs, but their contribution in the wealth was more than $57 \%$. The opposite happens if we compare the community structure near the source of Rio dos Sinos, analyzed by Becker et al. (2014). In that case, the epiphytic fern community presented a more equitable distribution with about $76.66 \%$ more wealth. 
The morphological characteristics, such as succulent rhizome, presence of trichomes and scales, are considered functional attributes (Rocha-Uriartt et al., 2016) and adaptive strategies of the epiphytic ferns against water stress (Benzing, 1989). In this study, these characteristics were also found in the inventoried specimens of Polypodiaceae, relating their occurrence to a drier environment, such as the lower stretch of the RSHB.

Polypodiaceae is also the most diverse within the epiphytic environment (Dubuisson et al., 2009), and is commonly found in urban and impacted environments (Sehnem, 1970; Becker et al., 2015). In these environments, plants have adaptive strategies that favor their development. For example, species of the genus Microgramma present a long-crawling rhizome that allows the occupation of extensive areas in the forophytes (Waechter 1998; Kersten and Silva, 2001). Specifically, M. vaccinifolia could have taken the highest IVs due to its aleopathic potential (Peres et al. 2009) and this species is cyanogenic, what can be reducing the predation (Santos et al., 2005) and increase its population. Microgramma squamulosa has a high sclerophylly index (Rocha et al., 2013), stomatal density and higher thickness of hypoderm in more polluted environments (Rocha et al., 2014), and these adaptations are important under water stress (Fahn and Cutler, 1992). Pleopeltis pleopeltifolia, on the other hand, reduces its exposed leaf surface, thus lessening the damage caused by the solar incidence and the lack of humidity in the environment, a strategy known as poikilohydry (Benzing, 1990), in which it can live with only $25 \%$ of its water content over long periods (Moran, 2012). These adaptations are fundamental for their survival in anthropic areas with less water availability.

Table 2. Phytosociological structure of species of epiphytic ferns inventoried in present study (São Leopoldo), in descending order of Specific Importance Value (IVs).

\begin{tabular}{|c|c|c|c|c|c|c|c|}
\hline Family & Species & nf & $\mathbf{n z}$ & FRf \% & FRz \% & NCr \% & IVs \% \\
\hline Polypodiaceae & Microgramma vaccinifolia (Langsd. \& Fisch.) Copel. & 35 & 118 & 53.8 & 58.1 & 60.3 & 57.4 \\
\hline Polypodiaceae & Pleopeltis pleopeltifolia (Raddi) Alston & 20 & 61 & 30.8 & 30.0 & 26.0 & 29.0 \\
\hline Polypodiaceae & Microgramma squamulosa (Kaulf.) de la Sota & 6 & 19 & 9.2 & 9.4 & 12.6 & 10.4 \\
\hline Polypodiaceae & Pecluma sicca (Lindm.) M.G.Price & 1 & 2 & 1.5 & 1.0 & 0.2 & 0.9 \\
\hline Polypodiaceae & Serpocaulon catharinae (Langsd. \& Fisch.) A.R.Sm. & 1 & 1 & 1.5 & 0.5 & 0.4 & 0.8 \\
\hline Polypodiaceae & Pleopeltis hirsutissima (Raddi) de la Sota & 1 & 1 & 1.5 & 0.5 & 0.4 & 0.8 \\
\hline Dryopteridaeae & Rumhora adiantiformis (G.Forst.) Ching & 1 & 1 & 1.5 & 0.5 & 0.1 & 0.7 \\
\hline
\end{tabular}

Legend: Nf and nz: number of forophytes and species occurrence zones, respectively; FRf: relative frequency in the forophytes; FRz: relative frequency in zones; NCr: relative coverage note; IVs: importance value.

\subsection{Rapid Habitat Assessment Protocol (RHAP)}

The result of the RHAP in the surveyed area totalled 33 points, thus classifying the stretch as impacted. The parameter "1-Occupancy type" had a maximum score. Being a Permanent Preservation Area (PPA), this riparian forest, although altered due to recreational trails, has original vegetation and few signs of suppression. At the opposite extreme, parameters 4 and 11 (vegetal cover over the river and type of substrate) scored zero. The absence of vegetation cover in the Rio dos Sinos gutter occurs due to the widening of the river, which also causes erosion in its banks. This reflects the deposition of mud on the river bed, demonstrated by the analysis of the RHAP.

The evaluation of the habitat quality is considered fundamental for the ecological integrity analysis, and the final scores reflect the level of conservation of the area (Barbour et al., 1999; Callisto et al., 2002). The result of the RHAP in the present study, obtained the same (impacted) framework from another stretch. Rocha-Uriartt et al. (2015) also analyzed the lower stretch of the RSHB. This location is at a distance of $12 \mathrm{~km}$ from the Imperatriz Leopoldina Park, showing that both are under the same environmental pressures and have the same characteristics of vegetation. A significant contribution to this result is caused by the population density and the consequent urban impact, mainly regarding the type of occupation of the margins and the 
devastation of the riparian forests (Barrella et al., 2000; Rodrigues and Gandolfi, 2000), which leads to the loss of environmental quality along the area.

Towards the mouth the river basin, the caracteristics of the vegetation follows the change of landscape. This is valid from the headwaters of formative streams to the main river, with heterogeneous environmental conditions towards the floodplain with more homogeneous characteristics (Barrella et al., 2000). Throughout the RSHB, this change in landscape is observed, evidenced by the RHAP score (Table 3), a significant reduction of epiphytic fern richness, and the concentration of IVs in a few species. In addition, the influence of lower altitude and significantly lower precipitation in the lower stretch of the RSHB (Rocha-Uriartt et al., 2015), prove to be natural causes and characteristics that become more homogeneous toward the mouth of the Rio dos Sinos.

Table 3. Score applied to RHAP parameters at Imperatriz Leopoldina Park compared to another study.

\begin{tabular}{ccccc}
\hline \multicolumn{5}{c}{ Comparative Studies } \\
\hline Assessed & $\begin{array}{c}\text { Rocha-Uriartt et al. (2015) } \\
\text { Parameter Stretch }\end{array}$ & $\begin{array}{c}\text { Middle Stretch } \\
\text { (Caraá) }\end{array}$ & $\begin{array}{c}\text { Lower Stretch } \\
\text { (Campo Bom) }\end{array}$ & $\begin{array}{c}\text { Lower stretch } \\
\text { (São Leopoldo) }\end{array}$ \\
\hline 1 & 4 & 2 & 0 & 4 \\
2 & 4 & 2 & 2 & 2 \\
3 & 4 & 2 & 2 & 2 \\
4 & 4 & 0 & 0 & 0 \\
5 & 4 & 2 & 2 & 2 \\
6 & 4 & 2 & 2 & 2 \\
7 & 4 & 2 & 2 & 2 \\
8 & 4 & 2 & 2 & 2 \\
9 & 5 & 3 & 3 & 2 \\
10 & 5 & 2 & 2 & 0 \\
11 & 5 & 2 & 2 & 3 \\
12 & 5 & 3 & 2 & 2 \\
13 & 5 & 2 & 2 & 3 \\
14 & 5 & 2 & 2 & 2 \\
15 & 5 & 2 & 0 & 33 \\
16 & 5 & 2 & 2 & Impacted Stretch \\
\hline Score & 72 & 32 & 27 & 2 \\
Assessment & Natural Stretch & Impacted Stretch & Impacted Stretch & \\
\hline
\end{tabular}

Legend: Parameters 1 - 8: maximum score (4: natural situation), intermediate (2: slight alteration) and minimum score: (0: severe alteration); Parameters 9 - 16: maximum score (4: natural situation), intermediate (3: slight alteration, 2: median alteration) and minimum score (0: severe change).

\section{FINAL CONSIDERATIONS}

This study showed that the chemical composition of rainwater is influenced by the environment of each area studied. In the upper stretch (Caraá), the greatest contribution is of marine origin, while in the lower stretch (São Leopoldo) it is basically derived from urbanization and industrialization.

In the riparian forest of Imperatriz Leopoldina Park, a reduction of the wealth and a simplification of the community structure of epiphytic ferns is evidenced, compared to the region of the source of the Rio dos Sinos. Likewise, the riparian forest of the area has lost its 
natural characteristics, and its environmental quality diminished according to the categories of RHAP and receives rainwater with a predominantly non-natural chemical composition.

The analysis of the riparian forest of the park applying different methods was an efficient tool to evaluate its environmental quality as it allowed the integration of a greater number of biotic and abiotic variables. The proposed integrated analysis can be applied to other scenarios as well.

\section{REFERENCES}

AKKOYUNLU, B. O.; TAYAN, C. M. Analyses of wet and bulk deposition in four different regions of Istanbul, Turkey. Atmospheric Environment, v. 37, p. 3571-3579, 2003. https://doi.org/10.1016/S1352-2310(03)00349-2

ALLEMAN, L. Y.; LAMAISON, L.; PERDRIX, E.; ROBACHE, A.; GALLOO, J. C. PM10 metal concentrations and source identification using positive matrix factorization and wind sectoring in a French industrial zone. Atmospheric Research, v. 96, p. 612-625, 2010. https://doi.org/10.1016/j.atmosres.2010.02.008

ALVES, D. D.; MIGLIAVACCA, D. M.; RODRIGUES, M. A. S.; ILLI, J. C.; BIANCHIN, L.; BENVENUTI, T. Concentrations of PM2.5-10 and PM2.5 and metallic elements around the Schmidt Stream area, in the Sinos River Basin, southern Brazil. Brazilian Journal of Biology, v. 75, p. 43-52, 2015. http://dx.doi.org/10.1590/1519-6984.00113suppl

AMERICAN PUBLIC HEALTH ASSOCIATION - APHA, AMERICAN WATER WORKS ASSOCIATION - AWWA, WATER ENVIRONMENTAL FEDERATION - WEF. Standard Methods for the examination of water and wastewater. 22 th Ed. Washington, D.C., 2012. P. 1360.

BARBOSA, M. D.; BECKER, D. F. P.; CUNHA, S.; DROSTE, A.; SCHMITT, J. L. Vascular epiphytes of the Atlantic Forest in the Sinos River basin, state of Rio Grande do Sul, Brazil: richness, floristic composition and community structure. Brazilian Journal of Biology, v. 75, p. 25-35, 2015. http://dx.doi.org/10.1590/1519-6984.0913

BARBOUR, M. T.; GERRITSEN, J.; SNYDER, B. D.; STRIBLING, J. B. Rapid bioassessment protocols for use in wadeable streams and rivers: periphyton, benthic macroinvertebrates, and fish. 2. ed. Washington: Environmental Protection Agency, 1999. 344 p.

BARRELLA, W.; PETRERE Jr., M.; SMITH, W. S.; MONTAG, L. F. A. As relações entre as Matas ciliares, os rios e os peixes. In: RODRIGUES, R. R.; LEITÃO-FILHO, H. F. (Orgs.). Matas ciliares: Conservação e recuperação. São Paulo: EDUSP/FAPESP, 2000. p. 187-208.

BARTHLOTT, W.; SCHMIT-NEUERBURG, V.; NIEDER, J.; ENGWALD, S. Diversity and abundance of vascular epiphytes: a comparison of secondary vegetation and primary montane rain forest in the Venezuelan Andes. Plant Ecology, v. 152, p. 145-156, 2001. http://dx.doi.org/10.1023/A:1011483901452

BECKER, D. F. P.; ROCHA-URIARTT, L.; JUNGES, F.; GRAEFF, V.; SCHMITT, J. L. Diagnóstico florístico e fitossociológico de samambaias e licófitas epifíticas em mata ciliar do Rio dos Sinos, RS, Brasil. In: UNIVERSIDADE FEEVALE (Org.). Feira de Iniciação Científica 2013: ciência, tecnologia e inovação: livro de destaques. 1. ed. Novo Hamburgo, 2014. p. 21-31. 
BECKER, D. F. P.; PADOIN, T. O. H.; NASCIMENTO, C. A.; ROBALSKI, J. L.; LINDEN, R.; SCHMITT, J. L. Riqueza e composição de epífitos vasculares em áreas urbanas da Bacia Hidrográfica do Rio dos Sinos, RS, Brasil. Pesquisas, Botânica, v. 68, p. 227-238, 2015 .

BENZING, D. H. Vascular epiphytes: general biology and related biota. Cambridge: Cambridge University Press, 1990. http://dx.doi.org/10.1017/CBO9780511525438

BENZING, D. H. Vascular epiphytism in America. In: LIETH, H.; WERGER, M. J. A. (eds) Tropical rain forest ecosystems: biogeographical and ecological studies. The Netherlands: Elsevier, 1989. http://dx.doi.org/10.1016/B978-0-444-42755-7.50013-4

BRASIL. Lei $\mathrm{n}^{\circ}$ 12.651, de 25 de maio de 2012. Diário Oficial [da] União, Brasília DF, 28 maio 2012.

BLUME, K. K.; COSTA, G. M.; CASSANEGO, M. B. B.; DROSTE, A. Genotoxicidade do ar em área urbana na região metropolitana de Porto Alegre, RS, Brasil. Revista Brasileira de Biociências, v. 12, p. 158-163, 2014.

CALliSTO, M.; FERREIRA, W.; MORENO, P.; GOULART, M. D. C.; PETRUCIO, M. Aplicação de um protocolo de avaliação rápida da diversidade de hábitats em atividades de ensino e pesquisa (MG-RJ). Acta Limnologica Brasiliensia, v. 34, p. 91-97, 2002.

CAMPOS, V. P.; COSTA, A. C. A.; TAVARES T. M. Comparação de dois tipos de amostragem de chuva: deposição total e deposição apenas úmida em área costeira tropical. Química Nova, v. 21, n. 4, p. 418-423, 1998.

COSTA, G. M.; PERY, C. T.; DROSTE, A. Active Versus Passive Biomonitoring of Air Quality: Genetic Damage and Bioaccumulation of Trace Elements in Flower Buds of Tradescantia pallida var. purpurea. Water Air Soil Pollution, p. 227-229, 2016. http://dx.doi.org/10.1007/s11270-016-2923-y

DUBUISSON, J.; HENNEQUIN, S.; SCHNEIDER, H. Epiphytism in ferns: diversity and history. Comptes rendus biologies, v. 332, p. 120-128, 2009. https://doi.org/10.1016/j.crvi.2008.08.018

ENGWALD, S.; SCHMIT-NEUERBURG, V.; BARTHLOTT, W. Epiphytes in rain forests of Venezuela - diversity and dynamics of a biocenosis. In: BRECKLE, S. W.; SCHWEIZER, B.; ARNDT, U. (Eds.). Results of worldwide ecological studies. Stuttgart Hohenheim: Verlag Günter Heimbach, 2000. p. 425-434.

FAHN, A.; CUTLER, D. F. Xerophytes. Encyclopedia of plant taxonomy. Berlin: Gebrüder Borntraeger, 1992.

FUNDAÇÃO ESTADUAL DE PROTEÇÃO AMBIENTAL HENRIQUE LUIZ HOESSLER - FEPAM. Qualidade Ambiental. Available in: http://www.fepam.rs.gov.br/qualidade/qualidade_sinos/sinos.asp. Access: 17 January 2016.

GREGORY, S. V.; SWANSON, F. J.; McKEE, W. A.; CUMMINS, K. W. An ecosystem perspective of riparian zones. BioScience, v. 41, n. 8, p. 540-551, 1992. http://dx.doi.org/10.2307/1311607 
HERRERA, J.; RODRÍGUEZ, S.; BAÉZ, A. P. Chemical composition of bulk precipitation in the metropolitan area of Costa Rica, Central America. Atmospheric Research, v. 94, p. 151-160, 2009. https://doi.org/10.1016/j.atmosres.2009.05.004

INSTITUTO BRASILEIRO DE GEOGRAFIA E ESTATÍSTICA - IBGE. Cidades. Available in: https://cidades.ibge.gov.br/brasil/rs/. Access: 31 March 2015.

INSTITUTO BRASILEIRO DE GEOGRAFIA E ESTATÍSTICA - IBGE. Cidades.Available in: https://cidades.ibge.gov.br/brasil/rs/. Access: 22 February 2017.

JOHANSSON, D. R. Ecology of vascular epiphytes in West African rainforest. Acta Phytogeographica Suecica, v. 59, n. 5, p. 1-129, 1974.

JOLY, C. A.; SPIGOLON, J. R.; LIEBERG, S. A.; SALIS, S. M.; AIDAR, M. P. M.; METZGER, J. P. W. et al. Projeto Jacaré-Pepira- O desenvolvimento de um modelo de recomposição da mata ciliar com base na florística regional. In: RODRIGUES, R. R.; LEITÃO-FILHO, H. F. (Orgs.). Matas Ciliares: conservação e recuperação. São Paulo: EDUSP/FAPESP, 2000. p. 271-287.

KERSTEN, R. A.; SILVA, S. M. Composição florística e estrutura do componente epifítico vascular em floresta da planície litorânea na Ilha do Mel, Paraná, Brasil. Revista Brasileira de Botânica, v. 24, n. 2, p. 213-226, 2001. http://dx.doi.org/10.1590/S010084042001000200012

KERSTEN, R. A.; WAECHTER, J. L. Métodos quantitativos no estudo de comunidades epifíticas. In: FELFILI-FAGG, J. M.; EISENLOHR, P. V.; MELO, M. M. R. F.; ANDRADE, L. A.; MEIRA-NETO, J. A. A. (Eds.). Fitossociologia no Brasil: métodos e estudos de caso. Viçosa: Editora UFV, 2011. p. 231-254.

KIELING-RUBIO, M. A.; BENVENUTI, T.; COSTA, G. M.; RODRIGUES, M. A. S.; SCHMITT, J. L.; DROSTE, A. Integrated environmental assessment of streams in the Rio dos Sinos basin in the State of Rio Grande do Sul, Brazil. Brazilian Journal of Biology, v. 75, n. 2, Suppl., p. 105-113, 2015. http://dx.doi.org/10.1590/1519-6984.1013

KRESS, W. J. The systematic distribution of Vascular Epiphytes: an update. Selbyana, v. 9, n. 1, p. 2-22, 1986. http://www.jstor.org/stable/41888782

LOYOLA, J.; ARBILLA, G.; QUITERIO, S. L.; ESCALEIRA, V.; MINHO, A. S. Trace metals in the urban aerosols of Rio de Janeiro city. Journal of the Brazilian Chemical Society, v. 23, p. 628-638, 2012. http://dx.doi.org/10.1590/S0103-50532012000400007

MANAHAN, S. E. Environmental chemistry. 8th Ed. Boca Raton: Lewis Publishers, 2005. p. 783.

MIGLIAVACCA, D. M.; TEIXEIRA, E. C.; MACHADO, A. C. de M.; PIRES, M. R. Composição Química da Precipitação Atmosférica no Sul do Brasil - Estudo Preliminar. Química Nova, v. 28, n. 3, p. 371-379, 2005a.

MIGLIAVACCA, D. M.; TEIXEIRA, E. C; WIEGAND, F.; MACHADO, A.C.M; SANCHEZ, J. Atmospheric precipitation and chemical composition of an urban site, Guaíba hydrographic basin, Brazil. Atmospheric Environment, v. 39, p. 1829-1844, 2005b. https://doi.org/10.1016/j.atmosenv.2004.12.005 
MIGLIAVACCA, D. M.; TEIXEIRA, E. C.; RODRIGUEZ, M. T. R. Composição química da precipitação úmida da região metropolitana de Porto Alegre, Brasil, 2005-2007. Química Nova, São Paulo, v. 35, n. 6, p. 1075-1083, 2012.

MORAN, R. C. A natural history of ferns. Portland: Timber Press, 2012. p. 302.

MOREIRA, T. C. L. Interação da vegetação arbórea e poluição atmosférica na cidade de São Paulo. 2010. 79 p. Dissertação (Mestrado em Ciências) - Universidade de São Paulo, Piracicaba, 2010. http://dx.doi.org/10.11606/D.11.2010.tde-17032010-134836

MUELLER, C. C. Gestão de matas ciliares. In: LOPES, I. V. (org.). Gestão Ambiental no Brasil: experiência e sucesso. Rio de Janeiro: Editora Fundação Getúlio Vargas, 1996. p. 185-214.

OLIVEIRA JUNIOR, R. C.; KELLER, M. M.; RAMOS, J. F. F.; BELDINI, T. P.; CRILL, P. M.; CAMARGO, P. B. et al. Chemical analysis of rainfall and throughfall in the Tapajós National Forest, Belterra, Pará, Brazil. Revista Ambiente \& Água, v. 10, n. 2, 2015. http://dx.doi.org/10.4136/ambi-agua. 1552

PEEL, M. C.; FINLAYSON, B. L.; McMAHON, T. A. Updated world map of the KoppenGeiger climate classification. Hydrology and Earth System Science, v. 11, p. 16331644, 2007. http://doi:10.5194/hess-11-1633-2007

PERES, M. T. L. P.; SIMIONATTO, E.; HESS, S. C.; BONANI, V. F. L.; CANDIDO, A. C. S.; CATELLI, C. et al. Estudos químicos e biológicos de Microgramma vacciniifolia (Langsd. \& Fisch.) Copel (Polypodiaceae). Quimica Nova, v. 32, n. 4, p. 897-901, 2009.

POISSANT, L.; SCHMITI, J.; BÉRON, P. Trace Inorganic Elements in Rainfall in the Montreal Island. Atmospheric Environment, v. 28, n. 2, p. 339-346, 1994. https://doi.org/10.1016/1352-2310(94)90109-0

PRADO, J.; SYLVESTRE, L. Lista de espécies da flora do Brasil: samambaias e licófitas. 2016.. Available in: http://floradobrasil.jbrj.gov.br/. Access: 08 March 2016.

PROSINOS. Caracterização Socioambiental da região da Bacia Hidrográfica do Rio dos Sinos. 2014. Available in: http://www.portalprosinos.com.br/conteudo.php?id=bacia. Access: 02 August 2014.

ROCHA L. D.; DROSTE, A.; GEHLEN, G.; SCHMITT, J. L. Leaf dimorphism of Microgramma squamulosa (Polypodiaceae): a qualitative and quantitative analysis focusing on adaptations to epiphytism. Revista de Biologia Tropical, v. 61, p. 291-299, 2013.

ROCHA, L. D.; COSTA, G. M.; GEHLEN, G.; DROSTE, A.; SCHMITT, J. L. Morphometric differences of Microgramma squamulosa (Kaulf.) de la Sota (Polypodiaceae) leaves in environments with distinct atmospheric air quality. Anais da Academia Brasileira de Ciências, v. 86, p. 1137-1146, 2014. http://dx.doi.org/10.1590/0001-3765201420130094

ROCHA-URIARTT, L.; CASSANEGO, M. B. B.; BECKER, D. F. P.; DROSTE, A.; SCHMITT, J. L. Diagnóstico ambiental de mata ciliar: uma análise integrada de parâmetros botânicos, meteorológicos e da genotoxicidade do ar atmosférico. Revista Brasileira de Ciências Ambientais, v. 35, p.102-115, 2015. 
ROCHA-URIARTT, L.; BECKER, D.; GRAEFF, V.; KOCH, N.; SCHMITT, J. Functional patterns and species diversity of epiphytic vascular spore-producing plants in riparian forests with different vegetation structure from southern Brazil. Plant Ecology and Evolution, v. 149, p. 261-271, 2016. https://doi.org/10.5091/plecevo.2016.1234

RODRIGUES, R. R.; NAVE, A. G. Heterogeneidade florística das matas ciliares. In: RODRIGUES, R. R.; LEITÃO-FILHO, H. F. (Orgs.). Matas Ciliares: conservação e recuperação. São Paulo: EDUSP/FAPESP, 2000. p. 45-71.

RODRIGUES, R. R.; GANDOLFI, S. Conceitos, tendências e ações para a recuperação de florestas ciliares. In: RODRIGUES, R. R.; LEITÃO FILHO, H. F. (Orgs.). Matas Ciliares: conservação e recuperação. São Paulo: EDUSP/FAPESP, 2000. p.233-247.

ROY, A.; CHATTERJEE, A.; TIWARI, S.; CHIRANTAN, S.; DAS, S. K.; GHOSH, S. K. et al. Precipitation chemistry over urban, rural and high altitude Himalayan stations in eastern India. Atmospheric Research, v. 181, p. 44-53. 2016. http://dx.doi.org/10.1016/j.atmosres.2016.06.005

SANTOS, M. G.; CARVALHO, C. E. M.; KELECOM, A.; RIBEIRO, M. L. R. C.; FREITAS, C. V. C. D.; COSTA, L. M. D. et al. Cianogênese em esporófitos de pteridófitas avaliada pelo teste do ácido pícrico. Acta Botanica Brasilica, v. 19, n. 4, p. 783-788, 2005.

SÃO LEOPOLDO. Prefeitura Municipal. Parque Imperatriz Leopoldina. Available in: https://goo.gl/qLsNPN. Acess: 19 January 2016.

SARDINHA, D. S.; BONOTTO, D. M.; GODOY, L. H.; CONCEIÇÃO, F. T.; MORENO, M. M. T. Influências geogênicas/antropogênicas na composição química das águas pluviais de Dois Córregos, bacia do Rio Jaú (SP). Geociências, v. 32, p. 577-585, 2013.

SCHUETTPELZ, E. et al. A community-derived classification for extant lycophytes and ferns. Journal of Systematics and Evolution, v. 54, p. 563-603, 2016. http://dx.doi.org/10.1111/jse.12229

SEHNEM, A. Polipodiáceas. In: REITZ, R. Flora Ilustrada Catarinense. Itajaí: Herbário Barbosa Rodrigues, 1970. p. 173.

SEINFELD, J. H.; PANDIS, S. N. Atmospheric chemistry and physics: from air pollution to climate change. 2. ed. New York: John Wiley \& Sons, 2006. p.1203.

SONG, F.; GAO, Y. Chemical characteristics of precipitation at metropolitan Newark in the US East Coast. Atmospheric Environment, 43, p. 4903-4913, 2009. https://doi.org/10.1016/j.atmosenv.2009.07.024

SOUZA, P. A.; De MELLO, Z. W.; MALDONADO, J.; EVANGELISTA, H. Composição química da chuva e aporte atmosférico na Ilha Grande, RJ. Química Nova, v. 29, p. 471476, 2006.

TAYLOR, S. R.; MCLENNAN, S. M. The geochemical evolution of the continental crust. Reviews in Geophysics, v. 33, p. 241-265, 1995. http://dx.doi.org/10.1029/95RG00262

UNITED STATES. Environmental Protection Agency - USEPA. Biological criteria for the protection of aquatic life. Ohio: Columbus, 1987. p. 120. 
XIAO, H. W.; XIAO, H. Y.; LONG, A. M.; WANG, Y. L.; LIU, C. Q. Chemical composition and source apportionment of rainwater at Guiyang, SW China. Journal of Atmospheric Chemistry, v. 70, p. 269-281, 2013. http://dx.doi.org/10.1007/s10874-013-9268-3

WAECHTER, J. L. Epifitismo vascular em uma floresta de restinga do Brasil subtropical. Revista Ciência e Natura, v. 20, p. 43-66, 1998.

WINDISCH, P. G. Pteridófitas da região Norte-Ocidental do Estado de São Paulo. 2. ed. São José do Rio Preto: UNESP, 1992. 110 p.

WU, Y.; XU, Z.; LIU, W.; ZHAO, T.; ZHANG, X.; JIANG, H. et al. Chemical compositions of precipitation at three non-urban sites of Hebei Province, North China: influence of terrestrial sources on ionic composition. Atmospheric Research, v. 181, p. 115-123, 2016. http://dx.doi.org/10.1016/j.atmosres.2016.06.009 